\title{
INTEGRASI MANAJEMEN KESISWAAN PENDIDIKAN FORMAL DAN NON FORMAL DI PONDOK PESANTREN AN-NAWAWI BERJAN PURWOREJO
}

Adi Wibowo

Program Studi Manajemen Pendidikan Islam

Sekolah Tinggi Agama Islam An-Nawawi Purworejo

Email: adiwibowo@stainnawawi.ac.id

\section{ABSTRAK}

Setiap lembaga pendidikan memerlukan manajemen pendidikan di dalam pengelolaannya, manajemen yang baik akan menjadikan lembaga pendidikan tersebut berhasil serta dapat menghasilkan mutu pendidikan yang memuaskan. Manajemen kesiswaan atau bisa disebut juga dengan pupil personal administration merupakan upaya pengelolaan atau mengatur peserta didik dimulai dari siswa masuk ke sekolah sampai siswa itu dinyatakan lulus, melihat sentralnya manajemen kesiswaan didalam lembaga pendidikan sekolah maka diperlukan integrasi dengan lembaga pendidikan baik formal maupun nonformal. Melihat dari fakta pondok An-Nawawi Berjan Purworejo yang berlatar belakang pondok pesantren salaf yang juga mengadakan pendidikan formal, pondok ini menggunakan manajemen kesiswaan yang diintegrasikan antara pendidikan formal dan non formal (pesantren). Maka artikel ini bertujuan untuk mengetahui bagaimana integrasi manajemen kesiswaan yang ada di pendidikan formal dan non formal pondok pesantren An-Nawawi Berjan Purworejo.

Kata kunci: Integrasi, manajemen kesiswaan, pondok pesantren

\section{ABSTRACT}

Every educational institution requires management of education in its management, good management will make the educational institution successful and can produce satisfactory quality of education. Student management or also referred to as personal administration pupils is an effort to manage or manage students starting from students entering school until the student is declared graduated, seeing the centrality of student management in school educational institutions, it is necessary to integrate with educational institutions both formal and non-formal. Seeing from the fact that An-Nawawi Berjan Purworejo cottage which incidentally is a salaf cottage which also holds formal education in general, this cottage uses student management which is combined between formal and non-formal education (pesantren). So this article aims to find out how the integration of student management in formal and non formal education An-Nawawi boarding school Berjan Purworejo

Key Words: integration, student management, islamic boarding school. 


\section{PENDAHULUAN}

Lembaga pendidikan yang mengutamakan substansi dari pendidikan didalam penyelenggaraannya akan memuat berbagai aturan yang berisi tentang bagaimana suatu sistem pada lembaga pendidikan tersebut dapat berjalan dengan baik dan mengikuti arus pendidikan di era globalisasi. Dalam hal ini diperlukan lembaga pendidikan yang dikelola dengan manajemen agar selalu menjaga mutu lembaga pendidikannya. Gambaran manajemen telah diungkapkan dalam AI-Qur'an surat As-Sajadah ayat 5 yang artinya Dia mengatur urusan dari langit ke bumi, kemudian (urusan) itu naik kepadanya dalam satu hari yang kadarnya adalah seribu tahun menurut perhitunganmu (As-Sajdah: 5). Surat tersebut menjelaskan bahwa Allah SWT mengatur segala urusan yang ada di langit dan di bumi. Stoner mengungkapkan yang dimaksud dengan manajemen adalah proses dalam membuat suatu perencanaan, pengorganisasian, pengendalian serta memimpin berbagai usaha dari anggota entitas/organisasi dan juga mempergunakan semua sumber daya yang dimiliki untuk mencapai tujuan yang ditetapkan (Baharun, 2016).

Manajemen kesiswaan memiliki beberapa tugas yang tentunya berkaitan dengan bidang kesiswaan. Yang menjalankan tugas tersebut adalah wakil kepala sekolah (waka kesiswaan) namun kepala sekolah juga tidak lepas dari tugas tersebut, karena meskipun ada wakil kepala sekolah bidang kesiswaan, kepala sekolah tetap memegang peran sangat penting karena keputusan akhir setiap kegiatan ada pada kepala sekolah. indikator keberhasilan kepala sekolah sebagai seorang pemimpin adalah kepuasan kerja guru, sebagai internal customer dan kepuasan siswa serta orang tua siswa sebagai external customer (Yakin, 2017). Adapun tugas utama manajemen kesiswaan antara lain adalah penerimaan murid baru, kegiatan kemajuan belajar, dan bimbingan dan pembinaan disiplin.

Dan adapun kegiatan-kegiatan atau ruang lingkup manajemen kesiswaan adalah terdiri dari penerimaan siswa baru, pembinaan dan pengembangan siswa, pencatatan dan pelaporan, serta kelulusan dan alumni (Dewi, Fitri, \& Soviya, 2018).

Penerimaan siswa baru merupakan peristiwa penting bagi suatu sekolah, karena peristiwa ini merupakan titik awal yang menentukan kelancaran tugas sekolah. Kesalahan dalam penerimaan siswa baru dapat menentukan sukses tidaknya usaha pendidikan di sekolah yang bersangkutan. Menjelang tahun ajaran baru proses penerimaan siswa baru harus sudah selesai, maka penunjukan panitia penerimaan siswa baru telah dilakukan oleh kepala sekolah sebelum tahun ajaran berakhir. Panitia penerimaan baru bersifat tidak tetap, jadi akan dibubarkan jika tugasnya telah selesai. Panitian penerimaan siswa baru biasanya ditunjuk oleh kepala sekolah yang anggotanya terdiri dari guruguru, staf tata usaha (Dewi dkk., 2018).

Pembinaan dan pengembangan siswa dilakukan sehingga anak mendapatkan bermacam-macam pengalaman belajar untuk bekal kehidupan yang akan datang. Untuk pengetahuan atau pengalaman belajar ini siswa harus melakukan bermacam-macam kegiatan. Melalui kegiatan pembinaan dan pengembangan siswa diproses untuk menjadi manusia yang diharapkan sesuai dengan tujuan pendidikan. Bakat, minat dan kemampuan siswa harus ditumbuhkan secara optimal melalui kegiatan kurikuler dan ekstrakutrikuler. 
Keberhasilan pembinaan dan pengembangan siswa diukur melalui proses penilaian yang dilakukan oleh lembaga pendidikan. Ukuran yang sering digunakan adalah naik kelas dan tidak naik kelas bagi siswa yang belum mencapai tingkat akhir serta lulus dan tidak lulus bagi siswa di tingkat akhir sebuah lembaga pendidikan (Dewi dkk., 2018).

Pencatatan dan pelaporan siswa di sebuah lembaga pendidikan (sekolah) sangat diperlukan. Kegiatan ini dimulai sejak siswa diterima di sekolah sampai mereka tamat atau meninggalkan sekolah. Pencatatan tentang kondisi siswa perlu dilakukan agar pihak lembaga dapat memberikan bimbingan yang optimal pada siswa. Sedangkan pelaporan dilakukan sebagai wujud tanggung jawab lembaga agar pihak-pihak terkait dapat mengetahui perkembangan siswa di lembaga tersebut. Pelaksanaan manajemen kesiswaan dapat berjalan dengan baik apabila dilakukan dengan teratur dan sistematik dengan cara pencatatan dan pelaporan. Adapun alat bantu yang diperlukan dalam manajemen ini antara lain adalah buku induk, klapper, daftar absen dan daftar pribadi. Semua anak yang sudah mendaftarkan diri kemudian diterima di suatu sekolah, secara otomatis menjadi tanggung jawab sekolah. Mereka perlu diurus, diatur, diadministrasikan sehingga mendapatkan perlakuan maksimal sebagaimana diharapkan oleh orang tua atau wali yang mengirimnya ke sekolah tersebut (Dewi dkk., 2018).

Kegiatan kelulusan adalah kegiatan paling akhir dari manajemen kesiswaan. Kelulusan adalah pertanyaan dari lembaga pendidikan sekolah tentang telah diselesaikannya pendidikan yang harus diikuti oleh siswa. Setelah siswa selesai mengikuti seluruh program pendidikan di suatu lembaga pendidikan dan berhasil lulus dalam ujian akhir, maka siswa tersebut diberikan surat keterangan lulus atau sertifikat, umumnya surat keterangan tersebut disebut dengan ijazah atau surat tanda tamar belajar (STTB) (Dewi dkk., 2018).

Jika membahas tentang macam-macam manajemen pendidikan Islam, terdapat beberapa sudut pandang yang dapat digunakan untuk mengupasnya, misalnya berdasarkan sumber, jenis lembaga, struktur organisasi, dan fungsinya (Kristiawan, Safitri, \& Lestari, 2017).

Jenis manajemen pendidikan Islam berdasarkan sumbernya terdapat dua jenis, yaitu manajemen pendidikan Islam dari sumber Islam dan manajemen pendidikan Islam dari sumber di luar Islam. Jika dilihat dari jenis lembaganya, maka manajemen Pendidikan Islam terdiri dari tiga macam, yaitu manajemen pendidikan Islam pondok pesantren, manajemen pendidikan Islam madrasah dan manajemen pendidikan Islam sekolah umum. Namun jika berdasarkan struktur kelembagaannya, manajemen Pendidikan Islam terdiri dari tujuh macam, yaitu manajemen kurikulum, manajemen kesiswaan, manajemen sarana prasarana, manajemen tenaga pendidik, manajemen hubungan masyarakat, manajemen keuangan, serta manajemen tenaga kependidikan. Sedangkan berdasarkan fungsinya manajemen Pendidikan Islam terdiri dari tiga macam yaitu perencanaan (planning), pengorganisasian (organizing), pergerakan/pelaksanaan (directing/actuating) dan pengawasan/pengendalian (Controlling) (Kristiawan dkk., 2017).

Namun artikel ini akan membahas manajemen pendidikan Islam berdasarkan struktur kelembagaannya yaitu manajemen kesiswaaan yang ada 
di pendidikan formal dan non formal Pondok Pesantren An-Nawawi Berjan Purworejo.

Melihat dari fakta Pondok Pesantren An-Nawawi Berjan Purworejo yang notabene adalah pondok salaf yang juga mengadakan pendidikan formal seperti sekolah umum pada umumnya, pondok ini menggunakan manajemen kesiswaan yang digabungkan antara pendidikan formal dan non formal (pesantren). Dengan konteks penelitian yang telah dipaparkan di atas, peneliti mengangkat judul: Integrasi Manajemen Kesiswaan Pendidikan Formal Dan Non Formal di Pondok Pesantren An-Nawawi Berjan Purworejo.

\section{METODE}

Penelitian ini menggunakan metode penelitian kualitatif. Adapun pengumpulan data diperoleh dari hasil wawancara, pengamatan yang dikaitkan dengan metode kualitatif. Alasan menggunakan metode ini karena peneliti sebelumnya sudah mengetahui kondisi yang ada di lokasi penelitian sehingga menjadikan kemantapan peneliti untuk mempermudah melakukan penelitian dengan jenis penelitian kualitatif. Objek penelitian ini difokuskan pada proses integrasi manajemen kesiswaan pada Lembaga formal dan non formal di Pondok Pesantren An-Nawawi Berjan Purworejo. Sumber data untuk menggali informasi yang digunakan pada penelitian ini yaitu: tenaga pendidik dan kependidikan madrasah dan pengurus pondok.

Metode pengumpulan data menggunakan teknik observasi yaitu suatu cara pengumpulan data melalui pengamatan panca indra yang kemudian diadakan pencatatan-pencatatan (Subaidi, 2019). Observasi dilakukan dengan cara peneliti mengamati langsung keadaan atau situasi yang ada di lingkungan Lembaga Pendidikan formal dan non formal di Pondok Pesantren An-Nawawi Berjan Purworejo dan juga menggunakan Teknik wawancara. Peneliti menggunakan metode wawancara ini dengan tujuan untuk memperoleh data yang berkaitan dengan integritas manajemen kesiswaan yang ada di Pondok Pesantren An-Nawawi Berjan Purworejo.

\section{HASIL DAN PEMBAHASAN}

Manajemen kesiswaan yang ada di pendidikan formal Pondok Pesantren An-Nawawi Berjan Purworejo dalam hal ini adalah madrasah aliyah memiliki sistem yang sangat berhubungan erat dengan Pondok Pesantren An-Nawawi Berjan Purworejo itu sendiri, dengan ini dapat dikatakan bahwa ada menajemen yang tidak terpisahkan antara Pondok Pesantren An-Nawawi Berjan Purworejo dan Madrasah Aliyah An-Nawawi yang bisa disebut juga dengan sekolah formal. Adanya penyatuan manajemen yang tidak terpisahkan ini bisa disebut dengan kerjasama atau integrasi. Menurut Kuntowijoyo, inti dari integrasi adalah upaya menyatukan, bukan sekedar menggabungkan (Rifai, Fauzan, \& Bahrissalim, 2014). Penggabungan antara manajemen kesiswaan Madrasah Aliyah An-Nawawi dengan Pondok Pesantren An-Nawawi Berjan Purworejo dilakukan secara utuh dan tidak terpisahkan. Tugas utama bagian kesiswaan meliputi penerimaan santri baru, kegiatan kemajuan belajar, bimbingan dan pembinaan disiplin di Madrasah Aliyah An-Nawawi tidak dapat dipisahkan dengan Pondok Pesantren An-Nawawi Berjan Purworejo. 
Salah satu tugas utama kesiswaan adalah pembinaan dan pengembangan siswa, hal ini dilakukan sehingga anak mendapatkan bermacam-macam pengalaman belajar untuk bekal kehidupan yang akan datang. Untuk pengetahuan atau pengalaman belajar ini siswa harus melakukan bermacam-macam kegiatan. Melalui kegiatan pembinaan dan pengembangan siswa diproses untuk menjadi manusia yang diharapkan sesuai dengan tujuan pendidikan. Keberhasilan pembinaan dan pengembangan siswa diukur melalui proses penilaian yang dilakukan oleh lembaga pendidikan. Ukuran yang sering digunakan adalah naik kelas dan tidak naik kelas bagi siswa yang belum mencapai tingkat akhir serta lulus dan tidak lulus bagi siswa di tingkat akhir sebuah lembaga pendidikan (Mursilah, 2015). Dengan menyatunya manajemen dalam bidang kesiswaan Madrasah Aliyah An-Nawawi Kediri dengan Pondok Pesantren An-Nawawi Berjan Purworejo maka dapat menelurkan peraturan sendiri, sehingga ketika ada kasus yang dialami siswa di pondok pesantren juga akan dapat mempengaruhi kenaikan kelas di dalam sekolah formal.

Sesuai dengan salah satu teori integrasi, sebuah analogi umum yang dipopulerkan Herbert Spencer menampilkan bagian-bagian masyarakat ini sebagai "organ" yang bekerja demi berfungsinya seluruh "badan" secara wajar (Farida, 2014). Dalam arti paling mendasar, istilah ini menekankan "upaya untuk menghubungkan, sebisa mungkin, dengan setiap fitur, adat, atau praktik, dampaknya terhadap berfungsinya suatu sistem yang stabil dan kohesif (Yakin, 2017). Kesiswaan Madrasah Aliyah An-Nawawi juga mempunyai kegiatan rutin yang dilaksanakan setiap tiga bulan sekali dalam forum Waka bidang kesiswaan bersama dengan lembaga-lembaga yang ada di pondok pesantren. Kegiatan ini sudah mempunyai kalender yang pasti yang sampai saat ini masih berjalan. Kegiatan ini dilakukan untuk membahas persoalan-persoalan mengenai akhlak dan adab siswa ketika di pondok. Sehingga keduanya berperan sebagai dua organ yang bekerja demi berfungsinya seluruh kegiatan yang ada di bidang kesiswaan secara wajar.

Mengingat tugas utama bagian kesiswaan sekolah adalah pertama, penerimaan santri baru. Kedua, kegiatan kemajuan belajar. Ketiga, bimbingan dan pembinaan disiplin. Salah satu tugasnya adalah menyediakan pendaftaran untuk siswa baru maka bagian kesiswaan juga melibatkan pengurus Pondok Pesantren An-Nawawi Berjan Purworejo, hal ini tentu karena adanya integrasi yang mendalam antara sekolah formal dan pondok pesantren. Penerimaan siswa baru merupakan peristiwa penting bagi suatu sekolah, karena peristiwa ini merupakan titik awal yang menentukan kelancaran tugas sekolah. Kelancaran dalam peneriamaan siswa baru dapat menentukan sukses tidaknya usaha pendidikan di sekolah yang bersangkutan. Panitia penerimaan baru bersifat tidak tetap, jadi akan dibubarkan jika tugasnya telah selesai. Panitia penerimaan siswa baru biasanya ditunjuk oleh kepala sekolah yang anggotanya terdiri dari guru-guru dan staf tata usaha. Pendaftaran siswa baru bagi mereka yang akan sekolah dan mondok di Pondok Pesantren An-Nawawi Berjan Purworejo keduanya tidak terpisah, hal ini jelas karena adanya integrasi atau kerjasama antara sekolah dan pondok. Keduanya bekerjasama untuk melaksanakan kegiatan rutin setiap tahun yaitu mengadakan penerimaan santri sekaligus siswa baru dalam satu waktu. 
Tujuan umum manajemen kesiswaan adalah untuk mengatur berbagai kegiatan dalam bidang kesiswaan agar kegiatan pembelajaran di sekolah dapat berjalan lancar, tertib dan teratur serta mencapai tujuan pendidikan sekolah (Mulyasa, 2007). Bimbingan konseling membantu Madrasah Aliyah An-Nawawi untuk memenuhi salah satu tujuan manajemen yang ada di sekolah yaitu melancarkan tugas yang menjadi tugas bagian kesiswaan untuk mempermudah bimbingan dan pembinaan disiplin siswa yang juga nyantri di pondok pesantren Pesantren An-Nawawi Berjan Purworejo.

Salah satu bentuk integrasi antara keduanya juga adanya pengurus pondok yang membidangi pendidikan dengan adanya program "belajar wajib" setiap malam di pondok pesantren untuk menumbuhkan semangat belajar di bidang sekolah formal di pagi harinya. Hal ini juga ada sangkut pautnya dengan tugas utama manajemen kesiswaan untuk kegiatan kemajuan belajar. Karena dengan ini wali kelas masing-masing angkatan sekolah formal yang dibentuk oleh pengurus pendidikan pondok pesantren diambil dari santri senior yang sudah menjadi mahasiswa hal ini tentu akan mempermudah dalam mengawasi santri yang juga menjadi siswa Madrasah Aliyah An-Nawawi berjan Purworejo

Di dalam Pondok Pesantren An-Nawawi Berjan Purworejo dalam hal kesiswaan memang tidak menamakan diri dengan bagian kesiswaan, namun program kerja yang dilaksanakan sama persis seperti program kerja yang biasa dilakukan oleh bidang kesiswaan. Jadi definisi manajemen kesiswaan yang ada di Pondok Pesantren An-Nawawi Berjan Purworejo adalah seksi keamanan, pendidikan dan madrasah Aliyah. Secara keseluruhan seksi keamanan mempunyai prioritas paling utama dalam membangun manajemen yang bersifat seperti manajemen bidang kesiswaan yaitu melewati diadakannya program Badan Kerja Catatan Pribadi Santri (BKCPS). Program ini merupakan program yang dibentuk oleh seksi keamanan untuk melihat perkembangan santri dalam segi akhlak. Di dalamnya terkumpul utusan seksi-seksi pengurus pondok dan lembaga khusus untuk membahas akhlak santri.

Dalam BKCPS yang melibatkan semua seksi dan lembaga yang ada di Pondok Pesantren An-Nawawi Berjan Purworejo ini juga mengumpulkan wali kelas perangkatan yang dibentuk sendiri oleh seksi pendidikan. Fungsi wali kelas di sini adalah untuk membina dan membimbing santri yang juga menjadi siswa di Madrasah Aliyah An-Nawawi Berjan Purworejo. Dalam BKCPS yang membahas semua masalah santri maka fungsi wali kelas dikumpulkan di sini adalah untuk mengetahui harus seperti apa para wali kelas memberi bimbingan dan pembinaan terhadap para santri yang juga sebagai siswa. Selain itu setiap malam di Pondok Pesantren An-Nawawi Berjan Purworejo wali kelas yang dibagi setiap angkatan ini membimbing siswi dalam program belajar wajib yang dikhususkan untuk mempelajari pelajaran yang ada di sekolah formal.

BKCPS membuat laporan santri setiap tiga bulan sekali untuk diinformasikan kepada wali santri yang ada di rumah dan juga sekolah formal agar lebih mendapatkan bimbingan khusus dari yang berwenang atas santri yang sekaligus yang menjadi siswa itu.

Namun khusus untuk Madrasah Aliyah An-Nawawi Berjan Purworejo seperti pada umumnya, madrasah ini mempunyai bidang kesiswaan yang program kerjanya adalah sebagai berikut: (1) menangani berbagai permasalahan dan pelanggaran yang mengakibatkan gangguan pada 
ketertiban Madrasah Aliyah, (2) mengkoordinir pengontrolan ke masing-masing kelas, (3) melaporkan adanya pelanggaran siswi kepada tenaga pengajar pembantu kepala Madrasah Aliyah dan wakil kepala Madrasah Aliyah yang terkait, (4) menangani perizinan, (5) mengontrol absensi harian siswi dan melaporkan kepada pembantu kepala Madrasah Aliyah yang terkait setiap bulan, (6) berkoordinasi dengan keamanan pondok pesantren, (7) melaporkan pelaksanaan tugas kepada wakil kepala madrasah Aliyah.

Selain itu setiap tahunnya pihak madrasah Aliyah An-Nawawi berjan Purworejo memberikan penghargaan terhadap siswi-siswi yang berprestasi dalam acara akhirussanah yang diadakan setiap akhir tahun.

\section{SIMPULAN}

Dari penjelasan di atas, maka penulis menyimpulkan sebagai berikut. Manajemen kesiswaan di Madrasah Aliyah An-Nawawi Berjan Purworejo adalah semua pengaturan kegiatan yang diadakan yang selalu berkaitan dengan siswa seperti penerimaan siswa baru, pembinaan dan bimbingan disiplin dan akhlak siswa maupun kegiatan yang memotivasi belajar siswa serta pengurusan kelulusan siswa. Manajemen kesiswaan di Madrasah Aliyah AnNawawi Berjan Purworejo meliputi kegiatan siswa dari awal masuk hingga akhir (tamat). Manajemen kesiswaan di Pondok Pesantren An-Nawawi Berjan Purworejo meskipun tidak dinamakan dengan manajemen kesiswaan namun secara nyata mempunyai tugas utama manajemen kesiswaan juga dilaksanakan dengan menggabungkan seluruh seksi-seksi dan lembagalembaga di dalam Pondok Pesantren An-Nawawi Berjan Purworejo dalam sebuah Badan Kerja Catatan Pribadi Santri (BKCPS). Dalam hal ini yang paling berperan penting adalah seksi pendidikan, seksi keamanan dan madrasah Aliyah. Ketiganya melaksanakan tugas yang merupakan tiga tugas utama bagian kesiswaan yang umumnya ada di sekolah formal, yaitu: penerimaan santri baru, kegiatan kemajuan belajar, bimbingan dan pembinaan disiplin.

Integrasi manajemen kesiswaan pendidikan formal dan non formal di Pondok Pesantren An-Nawawi Berjan Purworejo ini memang ada mengingat tugas utama bagian kesiswaan sekolah adalah pertama, penerimaan santri baru. Kedua, kegiatan kemajuan belajar. Ketiga, bimbingan dan pembinaan disiplin. Ketiganya tidak dapat berjalan dengan sempurna jika tidak ada integrasi antara manajemen kesiswaan pendidikan formal dan non formal di Pondok Pesantren An-Nawawi Berjan Purworejo, karena status siswa yang juga sebagai santri yang berada di bawah naungan yayasan yang sama yaitu yayasan An-Nawawi ini termasuk kategori santri yang nyantri di pondok pesantren kombinasi antara salaf dan khalaf, jadi kedua sistem bergabung menjadi satu termasuk manajemen kesiswaan dan pondok pesantren.

Jadi dengan demikian dapat diambil kesimpulan bahwasanya memang ada integrasi antara manajemen pendidikan formal dan non formal Pondok Pesantren An-Nawawi Berjan Purworejo mulai dari penerimaan siswa dan santri baru, kegiatan kemajuan belajar, serta bimbingan dan pembinaan disiplin. 


\section{REFERENSI}

Baharun, H. (2016). Manajemen Kinerja dalam Meningkatkan Competitive Advantage Pada Lembaga Pendidikan Islam. Jurnal At-Tajdid, 5(2), 243262.

Dewi, C. T., Fitri, N. W., \& Soviya, O. (2018). Neurosains dalam Pembelajaran Agama Islam. Ta'allum: Jurnal Pendidikan Islam, 6(2), 259-280. https://doi.org/10.21274/taalum.2018.6.2.259-280

Farida, A. (2014). Islamisasi Sains dan Saintifikasi Islam. Jurnal Multikultural \& Multireligius, 13(1), 16.

Kristiawan, M., Safitri, D., \& Lestari, R. (2017). Manajemen Pendidikan. Yogyakarta: CV Budi Utama.

Mulyasa, E. (2007). Manajemen Berbasis Sekolah. Bandung: PT Remaja Rosdakarya.

Mursilah. (2015). Manajemen Kesiswaan dan Manajemen Keuangan di SMA. Manajer Pendidikan: Jurnal Ilmiah Manajemen Pendidikan Program Pascasarjana, 9(3), 430-439.

https://ejournal.unib.ac.id/index.php/manajerpendidikan/article/view/1140 1948

Rifai, N., Fauzan, F., \& Bahrissalim, B. (2014). Integrasi Keilmuan Dalam Pengembangan Kurikulum Di UIN Se-Indonesia: Evaluasi Penerapan Integrasi Keilmuan UIN dalam Kurikulum dan Proses Pembelajaran. TARBIYA: Journal of Education in Muslim Society, 2(1), 13-34. https://doi.org/10.15408/tjems.v1i1.1108

Subaidi. (2019). Manajemen Biaya dan Sarana Prasarana Di SMAN 3 Pati dan MA Silahul Ulum Asempapan Trangkil Pati. Jurnal At-Tarbiyat: Jurnal Pendidikan Islam, 2(1), 69-87. http://jurnal.staiannawawi.com/index.php/At-Tarbiyat/article/view/146

Yakin, N. (2017). Studi Kasus Pola Manajemen Pondok Pesantren Al-Raisiyah di Kota Mataram. Ulumuna, 18(1), 199-220. https://doi.org/10.20414/ujis.v18i1.159 